\title{
AKUNTABILITAS PERGURUAN TINGGI ISLAM SWASTA
}

\section{A. Rusdiana}

STAI Al-Musdariyah Cimahi Jawa Barat

Jl. Kamarung No. 25 A Kel. Citeureup Kec. Cimahi Utara Kota Cimahi

40512- Jawa Barat

Email: rusdiana61@gmail.com

\begin{abstract}
ABSTRAK
Penelitian ini bertujuan mengkaji kebijakan dan program WASDALBIN, kendala dalam mengiplementasikan kebijakan WASDALBIN, langkah-langkah dalam mengimplementasikan kebijakan WASDALBIN PTAIS. Metode penelitian yang digunakan deskriptif analitik. Unit analisis dari penelitian ini ditentukan secara purposif, yaitu di 3 wilayah Kopertais I Jakarta, II Jabar Banten, dan IV Surabaya, yang dianggap mewakili keseluruhan wilayah Indonesia. Data dikumpulkan melalui wawancara mendalam, studi dokumentasi dan observasi. Hasil penelitian menunjukkan bahwa komunikasi kebijakan WASDALBIN kurang efektif. Para pelaksana kebijakan menganggap bahwa kebijakan WASDALBIN masih kurang jelas, konsisten dan tepat. Kualitas dan proporsi sumber daya kurang memadai. Kinerja pelaksana kebijakan kurang optimal. Struktur birokrasi dalam pelaksanaan WASDALBIN masih berbelitbelit, sehingga kurang efisien. Kelemahan ini hampir merata pada semua wilayah WASDALBIN yang diteliti, dengan sedikit variasi. Simpulan penelitian ini menunjukkan bahwa kebijakan WASDALBIN pada Kopertais belum dapat diimplementasikan secara optimal.
\end{abstract}

Kata Kunci: Efektifitas, Kebijakan WASDALBIN, Akuntabilitas.

\begin{abstract}
This study aims to assess policies and programs WASDALBIN, constraints in $W A S D A L B I N$ implement the policy, the steps in implementing policies WASDALBIN PTAIS. The method used descriptive analytic. The unit of analysis of this study determined purposively, is in 3 areas Kopertais I Jakarta, Banten West Java II, and IV Surabaya, which is considered to represent the whole territory of Indonesia. Data were collected through interviews, documentation and observation studies. The result of the research shows that communication is less effective $W A S D A L B I N$ policy. The policy implementers assume that $W A S D A L B I N$ policy is less clear, consistent and appropriate. The quality and the proportion of inadequate resources. Performance of policy implementing is less than optimal. The structure of the bureaucracy in the implementation WASDALBIN still convoluted, making it less efficient. This weakness is almost evenly in all regions studied WASDALBI, with slight variations. Conclusion This study shows that the policy WASDALBIN on Kopertais not be implemented optimally.
\end{abstract}

Keywords: Affectivity, WASDALBIN policy, Accountability. 


\section{PENDAHULUAN}

Perguruan Tinggi (Agama) Islam di masa depan menghadapi tantangan yang berat, karena pendidikan tinggi mengemban fungsi untuk meningkatkan kualitas sumber daya manusia. Tantangan ini dirasakan semakin berat lagi, karena ada sementara pendapat yang menyatakan bahwa lemahnya sistem pendidikan nasional juga dikaitkan dengan kesulitan krisis multi dimensi bangsa. Para analis pendidikan menyebutkan bahwa ada tiga faktor yang menyebabkan mutu pendidikan di Indonesia tidak mengalami peningkatan (Diknas, 2001:3-4): (1) kebijakan dan penyelenggaraan pendidikan nasional yang menggunakan pendidikan education production function atau input - output - analysis yang tidak dilaksanakan secara konsekuen, (2) penyelenggaraan pendidikan dilakukan secara birokratik sentralistik, (3) peran birokrasi dan masyarakat. Masalah-masalah pendidikan ini semakin tampak pada Perguruan Tinggi Islam, karena penyelenggaraan pendidikannya masih dilakukan secara birokratik sentralistik (berdasarkan prinsip dekonsentrasi). Dalam keadaan demikian, kebijakan publik memainkan peran penting.

Tantangan yang dihadapi Perguruan Tinggi (Agama) Islam saat ini, baik negeri (PTAIN) maupun swasta (PTAIS) adalah pola tata kelola yang baik (good governance) yang dicirikan oleh transparansi dan akuntabilitas. Tuntutan demikian tampak dari pernyataan John J Carson, seperti dikutip R. Eko Indrajit \& R. Djokopranoto, "Governance is a decision-making process for making rules and regulation which govern the conduct of and relationship between the various members of the colleges or university community." Pernyataan Carson tersebut memperlihatkan bahwa pengelolaan perguruan tinggi melibatkan suatu proses atau seni, sehingga para cendekiawan, mahasiswa, pengajar, administrator, dan pimpinan bergabung bersama di sekolah tinggi atau universitas, serta melaksanakan peraturan dan ketentuan yang bertujuan meminimalkan konflik, meningkatkan kerjasama, dan menjamin kebebasan individu tertentu.

Dalam rangka menjamin akuntabilitas pengelolaan PTAI (UIN/IAIN/STAIN/PTAIS), Kemenag melalui Keputusan Menteri Agama RI Nomor 156 Tahun 2004 tanggal 18 Maret 2004, melakukan pengawasan, pengendalian dan pembinaan (WASDALBIN) terhadap Perguruan Tinggi Agama Islam yang meliputi: (1) Rencana Induk Pengembangan (RIP); (2) Rencana Strategis; (3) kurikulum; (4) tenaga kependidikan; (5) calon mahasiswa; (6) sarana dan prasarana; (7) penyelenggaraan pendidikan yang meliputi kuliah, praktikum, kegiatan terencana, pembimbingan, dan penilaian hasil belajar; (8) penyelenggaraan penelitian; (9) penyelenggaraan pengabdian kepada masyarakat; (10) kerjasama, meliputi tukar-menukar sumber daya, kemahasiswaan, penelitian, penggembangan, dan penyelenggaraan program akademik; (11) administrasi dan pendanaan program, meliputi ketertiban administrasi, dan pendanaan; dan (12) pelaporan kegiatan proses penyelenggaraan program studi. 
Di lapangan, tugas pengawasan, pengendalian, dan pembinaan (WASDALBIN) pada PTAIS, dibantu dan dilaksanakan oleh 13 Koordinator Perguruan Tinggi Agama Islam Swasta (Kopertais) berdasarkan Keputusan Menteri Agama RI nomor 155 Tahun 2004 tentang Koordinatorat Perguruan Tinggi Agama Islam Swasta (Kopertais), secara institusional mempunyai tugas membantu Direktur Jenderal Pendididikan Islam dalam melaksanakan pengawasan, pengendalian, pembinaan, dan pemberdayaan PTAIS. Untuk menyelenggarakan tugas fungsinya sesuai SK Ditjen Pendis Nomor DJ.I/494/2007, maka Kopertais mempunyai tugas dan fungsi: (1) Pengawasan, (2) Pengendalian, dan (3) Pembinaan dan pemberdayaan terhadap PTAIS.

Dalam kenyataannya, sebagian besar PTAIS sangat sulit memenuhi persyaratan ini. Kebanyakan PTAIS, khususnya di daerah belum dapat memenuhi persyaratan dengan baik. Sering dijumpai suatu PTAIS dari fisik bangunannya saja tidak memadai, ditambah lagi dengan minimnya tenaga pengajar (dosen) yang memenuhi kualifikasi, baik dari segi pendidikan ataupun kewenangan mengajar (jabatan fungsional). Untuk mencapai beberapa kriteria administratif di atas, kebanyakan PTAIS sangat tergantung pada dukungan kebijakan pemerintah, pusat maupun dearah, mahasiswanya dan peran serta masyarakat. Pemasukan dana di luar Pemda dan uang kuliah dari mahasiswa masih minim, sumberdaya organisasi belum memadai. Oleh karena itu, tidaklah mengherankan apabila dalam kegiatan perkuliahan sepi mahasiswa, dan baru sibuk apabila menjelang ujian atau wisuda.

Penelitin ini bertujuan untuk memperoleh gambaran tentang implementasi kebijakan pengawasan, pengendalian, dan pembinaan (WASDALBIN) dalam mewujudkan akuntabilitas PTAIS di tiga Wilayah Kopertais I DKI Jakarta, Kopertais Wilayah II Jabar-Banten, dan Kopertais Wilayah IV Surabaya. Secara khusus penelitin ini bertujuan untuk mengkaji masalah-masalah yang mencakup: (1) Kebijakan dan program WASDALBIN di dalam mewujudkan Akuntabilitas PTAIS. (2) Implementasi kebijakan dan program WASDALBIN di dalam mewujudkan Akuntabilitas PTAIS, meliputi pelaksanaan kinerja, faktor-faktor yang mempengaruhi dan dampak dari implementasi kebijakan. (3) Masalah yang dihadapi di dalam mengiplementasikan kebijakan WASDALBIN di dalam mewujudkan Akuntabilitas PTAIS; (4) Langkah-langkah yang dilakukan oleh Kopertais dalam mengimplementasikan kebijakan WASDALBIN di dalam mewujudkan Akuntabilitas PTAIS.

Metode yang digunakan dalam penelitian ini adalah metode deskriptif analitik. Unit analisis dari penelitian ini ditentukan secara purposif, yaitu semua Kopertais di Pulau Jawa, yang dianggap mewakili keseluruhan wilayah Indonesia. Data dikumpulkan melalui wawancara mendalam dan studi dokumentasi terkait masalah penelitian. Analisis dilakukan secara kualitatif. Untuk mendapatkan data yang objektif dalam penelitian ini penulis menggunakan metode dan teknik pengumpulan data tertentu. Sebagaimana pendapat Surakhmad, Winarno (1985: 
131) bahwa "metode merupakan cara utama yang dipergunakan untuk mencapai tujuan".

Tujuan utama dari penelitian ini yakni untuk mendeskripsikan bagaimana implementasi kebijakan pengawasan, pengendalian dan pembinaan dalam menuju akuntabilitas Pendikan Tinggi Agama Islam di Kopertais Wilayah I DKI Jakarta, Kopertais Wilayah II Jawa Barat dan Banten dan Kopetais Wilayah IV Surabaya, sedangkan pendekatan analisis kualitatif digunakan atas pertimbangan bahwa a) pendekatan ini akan lebih adaptif bila dihadapkan dengan kenyataan yang kompleks; b) pendekatan ini memungkinkan hubungan antara responden dengan peneliti masuk dalam persoalan yang menjadi objek penelitian; c) pendekatan ini lebih peka dan lebih mudah masuk dalam persoalan dan memfokuskannya; d) penelitian ini merupakan penelitian kualitatif. Moleong (2001: 27) menekankan bahwa penelitian kualitatif berakar pada latar alamiah sebagai keutuhan. Penelitian kualitatif mengandalkan manusia sebagai alat penelitian, memanfaatkan metode, kualitatif analisis data secara induktif, mengarahkan sasaran penelitian pada usaha menemukan teori dari dasar, bersifat deskriptif, dan lebih mementingkan proses dari pada hasil. Bagaimanapun juga dengan menggunakan metoda kualitatif peneliti dapat memusatkan diri pada persoalan-persoalan aktual melalui pengumpulan data, susunan data, penjelasan data dan analisis data.

Nasution (1988:54) mengemukakan bahwa penelitian kualitatif adalah metode kualitatif tidak membutuhkan populasi dan sampel yang banyak, populasi tergantung pada konsep yang digunakan dan terbatas pada unitnya. Jumlah subyek penelitian tidak dikemukakan secara ketat tetapi tergantung pada tercapainya tendensi data. Sukmadinata (2007: 94) mengemukakan bahwa; "Penelitian kualitatif siklusnya belum selesai selama diketemukan hal baru. Penelitian kualitatif tidak ada penjumlahan jawaban yang ada hanya penyempurnaan jawaban". Metode kualitatif mempunyai sifat yang berbeda dengan metode yang bersifat kuantitatif. Perbedaannya tampak dalam desain penelitian dan proses penelitian. Dalam desain penelitian, metode kualitatif lebih bersifat terbuka, sedangkan metode kuantitatif bersifat ketat dalam arti sedikit sekali peluang untuk melakukan perubahan-perubahan. Ditinjau dari proses, penelitian kualitatif bersifat partisipatoris terhadap konteks yang diteliti sehingga instrumen penelitian sering dirinya sendiri, sedangkan dalam metode kuantitatif peneliti mempunyai jarak tertentu untuk menjaga keterlibatannya dalam konteks yang diteliti.

Sedangkan Prosedur dan Teknik pengumpulan data didasarkan pada prinsip yang dianjurkan oleh Naturalictic Approach yang melekat pada tradisi ilmu. sosial (Lofland \& Lofland, 1984) mengarah pada situasi dan kondisi setting penelitian, kejadian yang dialami oleh subyek penelitian individu atau, kelompok atas dasar latar belakang (biografi, histori dan hubungan) personal atau kelompok yang terjalin. Oleh Lofland \& Lofland, proses ini mencakup tiga tahap kegiatan, yaitu: 
1. Persiapan memasuki kancah penelitian (getting in). Agar proses pengumpulan data dan informasi berjalan sesuai rencana, peneliti terlebih dahulu telah menyiapkan segala sesuatu yang diperlukan, baik kelengkapan bersifat administratif maupun semua masalah dan persoalan berhubungan dengan latar dan subjek peneletian untuk mencari relasi awal. Ketika berusaha memasuki lokasi, penelitian, peneliti harus menempuh pendekatan informal dan formal, serta juga harus mampu menjamin hubungan yang akrab dengan informan. Untuk itu agar diperoleh suatu data yang valid, peneliti melakukan adaptasi dan proses belajar dari sumber data tersebut secara etis dan simpatik sehingga bisa mengurangi jarak antara peneliti dengan para informan. Peneliti berperilaku baik dalam kata, bahasa dan tindakan. Pada tahap ini yang diutamakan adalah bagaimana peneliti dapat diterima dengan baik pada waktu memasuki setting area.

2. Ketika berada di lokasi penelitian (getting along) atau memasuki situasi lokasi penelitian, maka hubungan yang terjalin harus tetap dipertahankan. Kedudukan subyek harus dihormati dan diberikan kebebasan untuk mengemukakan semua persoalan, data serta informasi yang diketahui, peneliti tidak boleh mengarahkan dan melakukan intervensi terhadap worldview subjek penelitian. Imajinasi dan daya nalar peneliti harus diasah dan dikembangkan untuk menangkap apa yang disampaikan, tindakan apa yang dilakukan, apa yang dirasakan serta kerangka mental dari dalam yang dimiliki subjek (emic). Berdasarkan emic yang diperoleh, peneliti mencoba memahami, menafsirkan dan mencoba untuk membuat pemaknaan baru atas worldview peneliti etic.

3. Pengumpulan data (logging to data) untuk mengumpulkan informasi dan data yang diperlukan, maka peneliti dengan menggunakan tiga teknik pengumpulan data, yang terdiri dari: (a) observasi; (b) wawancara secara mendalam in-dept interview; dan (c) dokumentasi, sehingga thick description didapatkan. Sedangkan pencatatan data dan penulisannya dilakukan dengan cara memanfaatkan bentuk-bentuk instrumen penelitian, diantaranya peneliti, field note, interview write ups, mapping, photograpic, sound serta beberapa dokumen penting.

\section{PEMBAHASAN}

\section{Akuntabilitas Pendidikan Tinggi Agama Islam}

Akuntabilitas suatu lembaga pendidikan tinggi dapat diartikan sejauh mana perguruan tinggi tersebut mempunyai makna dari para stakeholders-nya, dapat tidaknya kinerja (produk), prilaku pengelola dapat dipertanggung-jawabkan secara hukum, etika akademik, agama, dan nilai budaya. Daulat P Tampubolon, (2001: 123), menegaskan, akuntabilitas perguruan tinggi dapat dilihat yaitu: “(a) apakah peraturan yang ditetapkan oleh perguruan tinggi dapat dipertanggung jawabkan secara undang-undang? (b) apakah materi kuliah yang diberikan dosen 
dapat dipertanggung-jawabkan secara kurikuler dan etika akademik?, (c) apakah nilai hasil ujian (IP/IPK) yang diperoleh mahasiswa terpercaya?, (d) Apakah prilaku (sikap) kepelayanan para pengelola perguruan tinggi dapat dipertanggung-jawabkan secara hukum, etika, agama, dan nilai budaya?, (e) apakah penelitian yang dilakukan dan hasilnya tidak bertentangan dengan agama dan atau undang-undang?, serta (f) apakah perguruan tinggi mempunyai kode etik?" Akuntabilitas suatu perguruan tinggi merupakan hal yang sangat penting untuk menjaga mutu lulusannya dengan masyarakat pemakainya. Adanya "keunggulan" tertentu lulusannya, merupakan hal memberikan nilai tambah bagi lulusannya dan citra perguruan tinggi yang bersangkutan. Apalagi dalam pengembangan kurikulum sepenuhnya diserahkan kepada perguruan tinggi yang bersangkutan sehingga masa yang akan datang, kompetisi antara perguruan tinggi akan semakin ketat.

Temuan penelitian ini menunjukkan bahwa sebagian besar PTAIS masih belum akuntabel. Hal ini diindikasikan oleh nilai akreditasi dari setiap PTAIS. Kenyataan ini mengisyaratkan masih lemahnya implementasi kebijakan WASDALBIN yang dilakukan oleh Kopertais. Dengan perkataan lain, sesuai dengan tujuan penelitian ini, rendahnya akuntabilitas PTAIS disebabkan oleh tidak efektifnya implementasi kebijakan WASDALBIN. Tentu saja, terdapat beberapa PTAIS yang memiliki mutu pendidikan yang relatif tinggi. Akan tetapi, pada umumnya, PTAIS ini merupakan fakultas agama yang diselenggarakan oleh universitas di bawah Dikti Kemendiknas. Secara tidak langsung, pelayanan WASDALBIN fakultas agama tidak hanya berasal dari Kopertais, tetapi juga berasal dari Kopertis. Meskipun demikian, secara keseluruhan mutu PTAIS yang berada di bawah WASDALBIN Kopertais masih rendah. Konsekuensi logis dari rendahnya mutu pedidikan di PTAIS pun berdampak pada kemampuan daya saing PTAIS, baik di tingkat lokal maupun regional.

Dari penelitian ini ditemukan bahwa implemntasi kebijkan WASDABIN belum efektif, dikarenakan belum optimalnya pelaksanaan fungsi WASDALBIN yang dilakukan oleh Kopertais terhadap PTAIS disebabkan belum adanya kesesuaian antara program dengan pemanfaat, kesesuai antara program dengan organisasi pelaksana, dan kesesuaian antara kelompok pemanfaat dengan organisasi pelaksana, sebagai berikut:

1. Belum sesuainya antara program KMA/165/2004 dengan pemanfaat, ditandai dengan masih adanya kesenjangan antara apa yang ditawarkan oleh program WASDALBIN dengan apa yang dibutuhkan oleh Kopertais dan PTAIS sebagai kelompok sasaran (pemanfaat).

2. Belum sesuainya antara program dengan organisasi pelaksana, ditandai dengan masih adanya kesenjangan antara tugas Kopertais yang disyaratkan oleh program (Kep. Dirjen Pendin 494/2007) dengan kemampuan Kopertais dalam melaksakan WASDALBIN,

3. Belum sesuainya antara kelompok pemanfaat dengan organisasi pelaksana, ditandai dengan masih adanya kesenjangan antara syarat yang diputuskan 
KMA/156/2004 untuk dapat memperoleh output program akuntabilitas PTAIS dengan apa yang dapat dilakukan oleh Kopertais dan PTAIS sebagai kelompok sasaran program.

Hal-hal yang bisa diklaim menjadi kendala dalam implementasi kebijakan WASDALBIN dalam mewujudkan akuntabilats PTAIS, meliputi: (a) kesesuai program dengan pemanfaat, (b) kesesuai program dengan organisasi pelaksana, (c) kesesuaian antara kelompok pemanfaat dengan organisasi pelaksana.

\section{Kebijakan WASDALBIN PTAIS}

Dalam rangka menjamin akuntabilitas pengelolaan PTAI (UIN/IAIN/STAIN/PTAIS), Kemenag melalui Keputusan Menteri Agama RI Nomor 156 Tahun 2004 tanggal 18 Maret 2004, melakukan pengawasan, pengendalian dan pembinaan (WASDALBIN) terhadap Perguruan Tinggi Agama Islam yang meliputi: (1) Rencana Induk Pengembangan (RIP), (2) Rencana Strategis, (3) kurikulum, (4) tenaga kependidikan, (5) calon mahasiswa, (6) sarana dan prasarana (7) penyelenggaraan pendidikan yang meliputi: (kuliah, praktikum, kegiatan terencana, pembimbingan, dan penilaian hasil belajar), (8) penyelenggaraan penelitian, (9) penyelenggaraan pengabdian kepada masyarakat, (10) kerjasama, meliputi tukar-menukar sumber daya, kemahasiswaan, penelitian, penggembangan, dan penyelenggaraan program akademik, (11) administrasi dan pendanaan program, meliputi ketertiban administrasi, dan pendanaan, dan (12) pelaporan kegiatan proses penyelenggaraan program studi.

Tugas pengawasan, pengendalian, dan pembinaan (WASDALBIN) pada PTAIS, dibantu dan dilaksanakan oleh 13 Koordinator Perguruan Tinggi Agama Islam Swasta (Kopertais) berdasarkan Keputusan Menteri Agama RI nomor 155 Tahun 2004 tentang Koordinatorat Perguruan Tinggi Agama Islam Swasta (Kopertais), secara institusional mempunyai tugas membantu Direktur Jenderal Pendididikan Islam dalam melaksanakan pengawasan, pengendalian, pembinaan, dan pemberdayaan PTAIS. Untuk menyelenggarakan tugas fungsinya sesuai SK Ditjen Pendis Nomor DJ.I/494/2007, maka Kopertais mempunyai tugas dan fungsi: (1) Pengawasan, (2) Pengendalian, dan (3) Pembinaan dan pemberdayaan terhadap PTAIS.

\section{Implementasi Kebijakan WASDALBIN pada PTAIS}

Tujuan kebijakan publik yang dilakukan oleh negara adalah pengelolaan ruang publik beserta masalah-masalahnya dan menangani aspek-aspek kehidupan sosial dan ekonomi politik yang tidak mampu diselesaiakan oleh kekuatankekuatan mekanisme pasar (Laswell, 1971: 456). Wilson (1887: 456) menemukan bahwa kebijakan sebagai seperangkat aksi atau rencana yang mengandung tujuan politik dan mempunyai pengaruh sangat luas pada penyelesaian permasalahan publik. Terdapat beberapa tahap analisis yang harus dilakukan yaitu: (1) menetapkan agenda kebijakan (agenda setting), (2) merumuskan kebijakan (policy formulation), (3) mengadopsi kebijakan (policy adoption), (4) pelaksanaan/ 
implementasi kebijakan (policy implementation) dan (5) penilaian dan evaluasi kebijakan (policy assesment and evaluation). Lebin lanjut Dunn (1944) menegaskan bahwa kebijakan publik adalah serangkaian pilihan tindakan pemerintah untuk dilakukan atau tidak dilakukan (whatever governments choose to do or not todo) guna menjawab tantangan yang menyangkut kehidupan masyarakat. Selanjutnya mengacu pada Hogwood dan Gunn, Bridgman dan Davis (2004:25) menemukan bahwa kebijkan publik selalu berhubungan dengan keputusan-keputusan pemerintah sangat berpengaruh terhadap kehidupan masyarakat melalui instrumen-instumen kebijkan yang dimilikinya. Kebijakan publik adalah keseluruhan dari kegiatan pemerinyah baik aktivitas lansung maupun melalui agen-agennya yang mempengaruhi kehidupan warganya.

Kebijakan pendidikan merupakan bagian dari kebijakan publik di bidang pendidikan. Ensiklopedia Wikepedia dalam Nugroho (2008: 36) menjelaskan kebijakan pendidikan berkenaan dengan kumpulan hukum atau aturan yang mengatur pelaksanaan sistem pendidikan, yang tercakup di dalamnya tujuan pendidikan dan bagaimana mencapai tujuan tersebut. Sebagaimana yang dikemukakan oleh Mark Olsen, John Codd dan Anne-Marie O’Neil dalam Nugroho (2008: 36) dinyatakan "bahwa kebijakan pendidikan merupakan kunci bagi keunggulan, sehingga kebijakan pendidikan perlu mendapat prioritas dalam globalisasi". Salah satu argumen utamanya adalah bahwa globalisasi membawa nilai demokrasi. Demokrasi yang memberikan hasil adalah demokrasi yang didukung oleh pendidikan.

Ahli manajamen kebijakan David C. Korten (1988) (Tarigan, 1991) memandang, bahwa suatu program kebijakan akan berhasil dilaksanakan jika terdapat kesesuaian dari tiga unsur implementasi program. Pertama, kesesuaian antara program dengan pemanfaat, yaitu kesesuaian antara apa yang ditawarkan oleh program dengan apa yang dibutuhkan oleh kelompok sasaran (pemanfaat). Kedua, kesesuaian antara program dengan organisasi pelaksana, yaitu kesesuaian antara tugas yang disyaratkan oleh program dengan kemampuan organisasi pelaksana. Ketiga, kesesuaian antara kelompok pemanfaat dengan organisasi pelaksana, yaitu kesesuaian antara syarat yang diputuskan organisasi untuk dapat memperoleh output program dengan apa yang dapat dilakukan oleh kelompok sasaran program. Dalam perspektif manajemen kualitas terpadu, menurut Gasperz (2008: 28) "suatu organisasi jika ingin kompetitif dalam persaingan global tidak bisa mengabaikan tuntutan kebutuhan stakeholder serta mampu memuaskan pelanggan. Edwards III (1984: 9-10) mengajukan pendekatan masalah implementasi dengan terlebih dahulu mengemukakan dua pertanyaan pokok, yakni: (1) faktor apa yang mendukung keberhasilan implementasi kebijakan? dan (2) faktor apa yang menghambat keberhasilan implementasi kebijakan? Berdasarkan kedua pertanyaan tersebut dirumuskan empat faktor yang merupakan syarat utama keberhasilan proses implementasi, yakni komunikasi, sumber daya, sikap birokrasi atau pelaksana dan struktur organisasi, 
termasuk tata aliran kerja birokrasi. Empat faktor tersebut menjadi kriteria penting dalam implementasi suatu kebijakan.

Efektivitas implementasi kebijakan hanya akan dicapai apabila faktorfaktor kritis dari implementasi kebijakan dapat diatasi. Faktor-faktor kritis tersebut menurut George Edward III (1980:9-10) mencakup 4 variabel penentu kebijakan publik yaitu komunikasi, sumber daya, disposisi atau sikap, dan struktur birokrasi sehingga implementasi kebijakan menjadi efektif. Keempat variabel tersebut secara simultan dan berkaitan satu sama lain guna mencapai tujuan implementasi kebijakan. Secara lengkap, Edward III melukiskan hubungan antara variabel-variabel komunikasi, sumber daya, disposisi atau perilaku dan struktur birokrasi seperti terlihat pada gambar 1 di bawah ini:

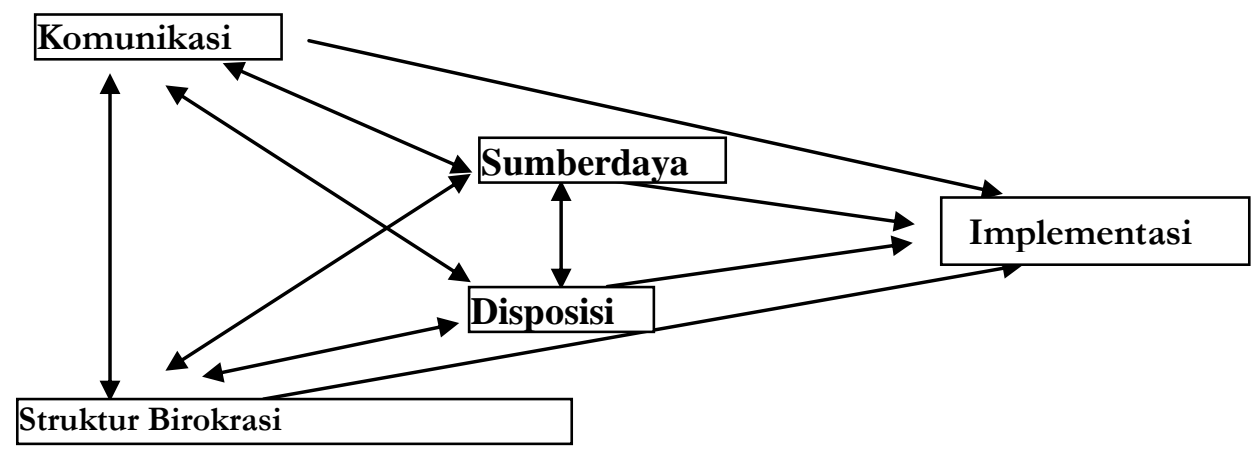

Tentang keempat variabel yang saling berhubungan dan berpengaruh dalam implementasi kebijakan, Edward III (1980: 10-12) mengemukakan yaitu:

1. Komunikasi; Komunikasi berkenaan dengan bagaimana kebijakan dikomunikasikan pada organisasi dan atau publik, ketersediaan sumber daya untuk melaksanakan kebijakan, sikap dan tanggap dari para pihak yang terlibat, dan bagaimana struktur organisasi pelaksana kebijakan. Komunikasi dibutuhkan oleh setiap pelaksana kebijakan untuk mengetahui apa yang harus mereka lakukan. Menurut Arifin (2005: 5) komunikasi adalah penyampaian informasi, ide, keterampilan, peraturan dan lain-lain menggunakan sarana tertentu kepada pihak yang berhak menerimanya. Elliot Jaques mendefinisikan komunikasi sebagai penyampaian berbagai macam perasaan, sikap dan kehendak baik secara langsung maupun tidak langsung, sadar atau tidak sadar. Menurut Wursanto (2002: 155), komunikasi adalah suatu proses penyampaian informasi dari satu pihak kepada pihak lain untuk mendapatkan saling pengertian. Menurutnya ada dua pengertian yang terkandung di dalamnya yaitu proses dan informasi. Proses komunikasi merupakan rangkaian dari langkah-langkah yang harus dilalui dalam pengiriman informasi. Informasi adalah segenap rangkaian perkataan, kalimat, gambar, kode atau tanda tertulis lainnya yang mengandung pengertian, buah pikiran atau pengetahuan apapun yang dapat dipergunakan setiap orang yang mempergunakannya untuk melakukan tindakan-tindakan 
yang baik, benar dan tepat. Bagi suatu organisasi, komunikasi merupakan suatu proses penyampaian informasi, ide-ide diantara para anggota organisasi secara timbal balik dalam rangka mencapai tujuan yang ditetapkan. Keberhasilan komunikasi ditentukan oleh 3 (tiga) indikator yaitu penyaluran komunikasi, konsistensi komunikasi dan kejelasan komunikasi.

2. Sumber daya; Ia berkenaan dengan sumber daya pendukung untuk melaksanakan kebijakan yaitu sumber daya manusia, kewenangan, informasi serta sarana dan prasarana. Sumber daya menjamin dukungan efektivitas implementasi kebijakan. (a) sumber daya manusia; sumber daya manusia merupakan aktor yang penting dalam pelaksanaan suatu kebijakan. Menurut Teguh Sulistiyani dan Rosidah (2003: 9) sumber daya manusia adalah potensi manusiawi yang melekat keberadaannya pada seseorang yang meliputi fisik dan non fisik. Potensi fisik adalah kemampuan fisik yang terakumulasi pada seseorang pegawai, sedangkan potensi non fisik adalah kemampuan seseorang pegawai yang terakumulasi baik dari latar belakang pengalaman, intelegensi, keahlian, keterampilan, dan hubungan personal. Keefektivan implementasi kebijakan sangat ditentukan oleh kualitas sumber daya manusia yang ada dalam organisasi, (b) sumber daya Informasi; Informasi adalah suatu sumber daya kedua yang penting di dalam implementasi kebijakan. Informasi penting untuk mengetahui bagaimana cara menyelesaikan suatu kebijakan. Aktor implementasi harus mengetahui apa yang harus dilakukan ketika menerima perintah untuk melaksanakan kegiatan atau kebijakan. Oleh karena itu, informasi yang disampaikan atau diterima haruslah jelas sehingga dapat mempermudah atau memperlancar pelaksanaan kegiatan atau kebijakan. (c) sumber daya kewenangan; Menurut Basu Iwastha (2000: 114) wewenang adalah hak untuk mengambil keputusan, hak untuk mengarahkan pekerjaan orang lain dan hak untuk memberi perintah. Sementara itu Henry Fayol (Agus Sabardi, 1997: 106) menyebutkan wewenang sebagai kebenaran untuk memberi perintah dan kekuasaan untuk memastikan ketaatan. Dengan demikian kewenangan berkaitan dengan hak atau kekuasaan untuk menjalankan kegiatan atau kebijakan yang telah ditetapkan. (d) sumber daya sarana dan prasarana; Sarana dan prasarana merupakan alat pendukung dalam pelaksanaan suatu kegiatan. Sarana dan prasarana dapat juga disebut dengan perlengkapan yang dimiliki oleh organisasi dalam menunjang atau membantu para pekerja di dalam pelaksanaan kegiatan mereka. Dengan kelengkapan sarana dan prasarana pada suatu organisasi, maka setiap kegiatan yang dijalankan oleh para pekerja akan lebih mudah dan cepat.

3. Disposisi atau sikap; Disposisi atau sikap, berkenaan dengan kesediaan dari para implementor untuk menyelesaikan kebijakan publik tersebut. Kecakapan saja tidak mencukupi, tanpa kesediaan dan komitmen untuk melaksanakan kebijakan. Disposisi menjaga konsistensi tujuan antara apa yang ditetapkan pengambil kebijakan dan pelaksana kebijakan. Sikap seseorang terhadap pekerjaannya mencerminkan pengalaman yang 
menyenangkan dan tidak menyenangkan serta harapan-harapannya terhadap pengalaman masa depan (Wexley dan Yuki, 2003:129). Sikap adalah cara seseorang memandang sesuatu secara mental (Atmosoeparapto, 2002: 11). Temuan penelitian Harvard School of Business menyebutkan bahwa $85 \%$ faktor penentu keberhasilan adalah sikap (Atmosoeprapto, 2002: 11). Dengan demikian dapat dikatakan bahwa kunci keberhasilan kegiatan atau implementasi kebijakan adalah sikap pekerja terhadap penerimaan dan dukungan atas kebijakan atau dukungan yang telah ditetapkan.

4. Struktur birokrasi; Struktur birokrasi berkenaan dengan kesesuaian organisasi birokrasi yang menjadi penyelenggara implementasi kebijakan publik. Tantangannya adalah bagaimana agar tidak terjadi bureaucratic fragmentation karena struktur ini menjadikan proses implementasi menjadi jauh dari efektif. Struktur birokrasi menjelaskan susunan tugas dari para pelaksana kebijakan, memecahkannya dalam rincian tugas serta menetapkan prosedur standar operasi. Dwidjowijoto (2008: 447) menyatakan bahwa di Indonesia sering terjadi inefektivitas implementasi kebijakan karena kurangnya koordinasi dan kerja sama di antara lembaga-lembaga negara dan atau pemerintah. Menurut Edward III (1980: 25) ada 2 indikator penting dalam struktur organisasi yaitu standar operasi prosedur dan fragmentasi organisasi. Standar operasi prosedur sebaiknya dibuat secara sederhana namun tetap tidak mengurangi makna sehingga tidak menyulitkan aparat pelaksana. Standar operasi prosedur merupakan tanggapan internal terhadap waktu yang terbatas dan sumbersumber dari pelaksana serta keinginan untuk keseragaman dalam bekerjanya organisasi-organisasi yang kompleks dan tersebar luas. Dengan menggunakan standar operasi prosedur, para pelaksana dapat memanfaatkan waktu yang tersedia dengan efisien. Fragmentasi organisasi adalah penyebaran tanggung jawab pelaksanaan tugas sehingga tidak tumpang tindih (duplikasi) dengan tetap mencakup pada pembagian tugas secara menyeluruh. Fragmentasi organisasi terutama berasal dari tekanan-tekanan di luar unit birokrasi, seperti legislatif, kelompok-kelompok kepentingan, pejabat-pejabat eksekutif, peraturan-peraturan dan sifat kebijakan yang mempengaruhi organisasi (Edward III, 1980: 135).

Sebagaimana tampak dari temuan sebelumnya, Kopertais adalah salah satu unsur penting dalam mengimplementasikan kebijakan WASDALBIN terhadap PTAIS. Akan tetapi jika ditafsirkan berdasarkan kerangka teoritis mengenai implementasi kebijakan, dapat dikatakan bahwa perannya sebagai lembaga pelaksana kebijakan belum optimal. Hal ini terkait dengan ketidakfahaman mereka tentang penjabaran lebih lanjut dari isi kebijakan WASDALBIN KMA 156/2004 sebagaimana dijabarkan dalam Keputusan Dirjen Nomor DJ.I/494/2007 tentang tugas, fungsi, dan mekanisme kerja Kopertais. Tidak adanya kesepahaman ini disebabkan oleh lemahnya aspek komunikasi kebijakan dari pembuat kebijakan (Menteri Agama RI) kepada pelaksana kebijakan, khususnya Kopertais. Masing-masing Kopertais mempunyai pemahaman yang 
berbeda tentang isi kebijakan. Perbedaan pemahaman ini berimplikasi pada perbedaan mekanisme pengawasan, pengendalian, dan pembinaan PTAIS di wilayah masing-masing Kopertais. Kekurang optimalan pelaksanaan WASDALBIN yang dilakukan oleh Kopertais ini diperparah oleh kesalahpahaman tentang isu otonomi pendidikan. Hal ini member kesan bahwa Kopertais tidak boleh melakukan intervensi terhadap PTAIS, termasuk dalam hal WASDALBIN. Dari tiga Kopertais yang diteliti, hanya satu Kopertais yang relatif dapat mengimplementasikan kebijakan WASDALBIN secara optimal. Dua Kopertais lainnya belum optimal. Kopertais yang optimal dalam mengimplementasikan kebijakan WASDALBIN memiliki status kelembagaan sebagai institut (IAIN), sedangkan Kopertais yang kurang optimal dalam mengimplementaskan kebijakan WASDALBIN mempunyai status kelembagaan universitas (UIN). Hal ini disebabkan IAIN memiliki bidang keilmuan yang sama dengan PTAIS yang dibinanya, sedangkan UIN selain membina program studi yang diselenggarakan PTAIS, juga pada saat yang sama membutuhkan WASDALBIN dari Diktis, khususnya untuk prodi-prodi umum.

Konsekuensi logis dari ketidaksepahaman atas isi kebijakan, maka setiap mempunyai perbedaan sumber daya, baik dalam pengertian sumberdaya manusia, sumber daya finansial, maupun sumber daya sarana-prasarana. Selain terhadap lemahnya sumber daya, hal inipun memperlihatkan ketidakseragaman dalam penyusunan struktur birokrasi pada setiap Kopertais, dalam rangka akselerasi implementasi WASDALBIN terhadap Kopertais. Pada akhirnya, kelemahan sumberdaya dan struktur birokrasi menyebabkan rendahnya kinerja aparat pelaksana WASDALBIN pada setiap wilayah Kopertais. Secara keseluruhan, lemahnya sumberdaya, struktur birokrasi, dan kinerja Kopertais berimplikasi pada lemahnya fungsi Kopertais dalam mengimplementasikan kebijakan WASDALBIN.

\section{SIMPULAN}

KMA Nomor 156 tahun 2004, tentang pedoman WASDALBIN, dengan tujuan dalam rangka penjaminan akuntabilitas PTAI, menjadi tugas Dirjen Pendis. Dirjen Pendis dalam WASDALBIN terhadap PTAIS, dibantu oleh Kopertais. Untuk tugas pembantuan tersebut, Dirjen Pendis mengeluarkan surat keputusan Nomor DJ.I/494/2007 tentang Tugas, fungsi dan mekanisme kerja Kopertais. Programnya menitikberatkan pada: (a) pengawasan, (b) pengendalian, (c) pembinaan dan pemberdayaan PTAIS. Implentasi kebijakan KMA/156/2004 dalam rangka penjaminan akuntabilitas PTAIS yang dilaksanakan oleh Kopertais dalam bentuk kegiatan pengawasan, pengendalian mutu, pembinaan, pemberdayaan PTAIS dalam bidang kelembagaan, akademik, ketenagaan, sarana dan prasarana. Efektifitas pelaksanannya didukung oleh komunikasi, sumber daya, disposisi atau sikap, struktur birokrasi. Sedangkan dampak dari kegiatan WASDALBIN, secara kuantitas telah membantu terhadap upaya pemerintah dalam hal pemerataan akses pendidikan, namun secara kualitas belum mencapai 
pada sasaran yang diharapkan. Kendala dalam implementasi kebijakan WASDALBIN terhadap PTAIS pada Kopertais, menyangkut sifat kebijakan (content of policy) dan lingkungan di mana kebijakan tersebut diimplementasikan (context of implementation). meliputi: (1) kesesuai KMA/156/2004 dengan kondisi lingkungan PTAIS sebagai pemanfaat, (2) kesesuain KMA/156/2004 dengan organisasi Kopertais sebagai pelaksana, (3) kesesuaian antara PTAIS dengan organisasi Kopertais. Upaya-upaya yang dilaksanakan oleh Kopertais dalam mengimplentasi kebijakan WASDALBIN untuk menjamin akuntabilitas PTAIS, dilakukan berdasarkan tugas yang tercermin pada visi, misi Kopertais yang dijabarkan melalui efektifitas pengawasan, pengendalian, pembinaan dan pemberdayaan PTAIS. Upaya-upaya dilaksanakan, merupakan komitmen Kopertais yang menjadi kewajibannya untuk mewujudkan akuntabelitas PTAIS.

\section{DAFTAR PUSTAKA}

Arifin, Zaenal, 2005. Teori Keuangan dan Pasar Modal, Yogyakarta: Ekonisia,

Badan Pengawasan Keuangan dan Pembangunan, 2007. Sistem Pengendalian Manajemen,

Departemen Agama RI-Dirjen Pendidikan Islam, Panduan Pendirian PTAI di Lingkungan Departemen Agama, www.ditpertais.net/panduan.pdf (diakses pada 1 Mei 2008).

Direktorat Pendidikan Tinggi Islam-Dirjen Pendidikan Islam DEPAG RI, et.al. 2005. Pengembangan Kurikulum Berbasis Kompetensi di PTAI. Yogyakarta: Pustaka pelajar.

Direktorat Pendidikan Tinggi Islam-Dirjen Pendidikan Islam DEPAG RI, http://www. ditpertais.net/06/profil.asp (diakses pada 20 Mei 2008).

Dwidjowijoto, R. N. 2008. Public Policy. Jakarta: Elek Media Komputindo.

Edwards III, George C. 1980. Implementing Public Policy. Washington: Quarterly Press.

Indonesia, Inpres RI Nomor 7 Tahun 1999 Tentang Akuntabilitas Kinerja Instansi Pemerintah, 1999

Indrajit, R. Eko, et.al. 2006. Manajemen Perguruan Tinggi Modern. Yogyakarta: Andi Offset.

Kenneth, N. Wexley, dan Gary, A. Yuki. 2003. Perilaku Organisasi dan. Psikologi Personalia. Jakarta: PT Rineka Cipta

Kep. Dirjen Pendidikan Islam, No. DJ.I/494/2007, tentang Tugas, fungsi dan Mekanisme Kerja Koordinatorat Perguruan Tinggi Agama Islam Swasta.

KMA. Nomor 155 Tahun 2004, tentang Koordinator Perguruan tinggi agama Islam

KMA. Nomor 156 Tahun 2004, tentang Pedoman Pengawasan, pengendalian, Pembinaan Perguruan tinggi Agama Islam

KMA. Nomor 394 Tahun 2003, tentang Pedoman Perguruan Tinggi Agama

Korten, David C dan Syahrir. 1980. Pembangunan Berdimensi Kerakyatan, Jakarta: Yayasan Obor Indonesia,

Lasswell, Harold D. 1971. A Preview of Policy Sciences. New York, 
Lofland, John \& Lyn H. Lofland. 1984. Analyzing Social Settings :A Guide to. Qualitative Observation and Analisys Belmot Call.: Word Wads Publising Company

Macmillan, Woodrow Wilson. 1887. "The study of administration”, Political Science Quarterly no. 2 June, pp. 197-222.

Moleong Lexy, 2001, Metodologi Penelitian Kualitatif, Bandung: Remaja Rosdakarya.

Nugroho, Eko, 2008. Sistem Informasi Manajemen: Konsep, Aplikasi \& Perkembangannya. Yogyakarta; ANDI.

Pedoman Akademik Kopertais Wilayah I. DKI Jakarta tahun 2009

Peraturan Pemerintah Nomor 60 Tahun 1999 tentang Pendidikan Tinggi

Peraturan Presiden Nomor 7 Tahun 2005 tentang Rencana Pembangunan Jangka Menengah Nasional (RPJMN) Tahun 2004-2009.

S. Nasution, 1988, Metode Penelitian Naturalistik Kualitatif, Bandung: Tarsito,.

Sabardi, Agus, 1997. Pengantar Manajemen, Yogyakarta: Unit Penerbit Dan Percetakan. Akademi Manajemen Perusahaan YKPN

SK. Mendiknas, Nomor 184/U/2001 tentang Pedoman Pengawasan Pengendalian dan Pembinaan Program Diploma, Sarjana dan Pascasarjana di Perguruan Tinggi.

Sukmadinata, 2006. Pengendalian Mutu Pendidikan Konsep, Prinsip, Instumen, Bandung: Reflika Aditama.

Sulistiyani, Teguh, Ambar dan Rosidah. 2003. Manajemen Sumber Daya Manusia. Yogyakarta: Graha Ilmu.

Swastha, Basu, 2000. Pengantar Bisnis Modern, Pengantar Ekonomi Perusahaan. Modern, Jakarta: Liberty.

Tampubolon P. 2001. Perguruan Tinggi Bermutu. Penerbit Blantika, Jakarta.

Tarigan, Antonius. 2000. Implementasi Kebijakan Jaring Pengaman Sosial: Studi Kasus Program Pengembangan Kecamatan di Kabupaten Dati II Lebak, Jawa Barat, Tesis Masigter Administrasi Publik UGM Yogyakarta.

Undang-Undang Nomor 20 Tahun 2003 tentang Sistem Pendidikan Nasional.

Winarno, Budi. 2002. Teori dan Proses Kebijakan Publik, Yogyakarta: Media Pressindo. 